\title{
Explicit ESL/EFL Reading-writing Connection: An Issue to Explore in ESL/EFL Settings
}

\author{
Ali S. Alghonaim \\ Department of English and Translation, College of Arabic and Social Studies, Qassim University, Buridah, Saudi \\ Arabia
}

\begin{abstract}
This paper tries to explore the explicit relationship between reading and writing from ESL/EFL perspectives. The reading-writing connection has long been established in language literacy. Yet, this paper specifically focuses on the usefulness and effectiveness as well as the need for the explicit connection between the two language skills in ESL/EFL settings. It compares between Arabic rhetoric and English rhetoric as two opposite language systems. This paper tries to relate some issues in natural settings in Saudi Arabia in relation to the status of reading and writing in real classrooms and writing teachers' strategies. Finally, the paper explores the composition teachers' role and knowledge in making this explicit connection significant to ESL learners of writing. This paper cites some examples that the author experienced in reading and writing courses when he was an EFL student enrolled in English department.
\end{abstract}

Index Terms - reading, writing connection, explicit connection, meaning connection, instructional connection, Arabic and English rhetoric, writing motivation, writing teachers

\section{INTRODUCTION}

Writing constitutes what many people report as the most frustrating skill in language. Unlike speaking, writing doesn't come naturally to human beings (Dobrovolsky, O'Grady). Omaggio (2001) states that writing in a second language is not just a matter of transferring new codes into the second language. Rather it involves mastering several skills. This is based on the assumption that, contrary to the oral language skills, academic language skills should receive teaching and training (Coady, 1993). This shows that writing requires special learning efforts. Additionally, Kroll (2001) says that teaching academic writing for even native speakers of English sounds challenging. However, Silva refers to research studies showing that L2 writers face different kinds of difficulties that have to be acknowledged and emphasized (cited in Kroll, 2001). One important factor that may help ESL/EFL students approach the complex task of writing is to constantly and appropriately use different strategies for writing. Reading for writing represents one of these strategies that learners should use when writing compositions or essays. Reading and writing were never completely removed from English as a Second Language (ESL) curricula. However, during the early 1980s there was a shift toward oral/aural instructional goals and practices. That shift was motivated by learners' need to communicate in the target language (Rabideau, 1993). This paper examines the close relationships between reading and writing and how reading can enhance second language writing. In several cases throughout this paper, I try to relate some issues to my experience as I was an EFL student taking reading and writing courses.

\section{THEORIES}

Integrating reading with writing is based on the assumption that language is viewed as a whole constituent. The Whole Language Approach argues that writing and reading should be taught together because learning becomes easier. Rigg claims that "if language is not kept whole, it is not language anymore" (as cited in Richards \& Rodgers, 2001). Although Whole language is a theory for young children, it has been extended to the field of ESL. According to the Whole Language approach, reading and writing complement each other. In other words, language modalities should be taught simultaneously (Ramirez, 1995). This means that students treat language as one continuum. Therefore, they are predisposed to apply what they read to what they write and vice versa. Different research studies show that those who read more, write better.

Composition courses based on the connection between reading and writing were first developed for native English writers. There are numerous textbooks which prepare native English-speaking students to write compositions after they read articles on the same topics. The number of ESL (English as a Second Language) composition textbooks of this nature is comparatively small (Shih, 1986, pp. 635-36). Recently, however, the "reading/writing connection" has also become a buzz phrase in ESL composition pedagogy.

Like Communicative Language Learning, Whole Language focuses on real activities that relate to the students' lives and needs (Richards \& Rodgers, 2001). Accordingly, learners can use authentic texts in order to develop writing for personal and social purposes. Freeman and freeman (1989) argue that whole language approach functions on the principle that when learners see a purpose for their activities, learning takes place. Edelsky (1986) calls the product of this kind of writing" authentic writing." 


\section{The RELATIONSHIPS BETWEEN READING AND WRITING}

Reading and writing relate to each other in a number of ways. Although reading mostly involves an intake process of ideas and writing involves the output process, these two language areas have some related connections in classrooms that teachers should be aware of in order to develop more effective instructions. Flahive and Bailey (1993) believe that reading and writing share some common processes that are generally directed toward the creation of meaning. The next section will cover three areas of reading/writing connection: meaning connection, language connection, and instructional connection.

\section{Areas of Reading-Writing Connection}

\section{1- Meaning Connection}

Meaning, or content, is so essential to reading and writing. Usually writers make meaning by word selection. Readers, similarly, construct meaning by use of knowledge about the language and it's words (Savage, 1998). Additionally, writers focus on the main idea of the text, known as the topic sentence. In other words, they place their topic sentence which carries the core meaning of a particular passages or text then provide some supporting ideas for this topic sentence. Actually, this technique is explicitly demonstrated in text books where readers look for the main idea of the text to grasp the meaning and then read for further development of the main sentence.

Teachers' and students' awareness of this connection helps them develop more effective use of the two language skills in a way that they can enhance their writing ability. Also it is crucial to attract the students' attention to this relationship when reading and writing. This relationship is so obvious, yet neglected in classrooms. When I was in my undergraduate study, although English was my major, I had never received this kind of relationship in the classroom because this concept does not exist at all. In a four-year college, I had never been exposed to examine the useful connection between reading and writing although the two language skills were taught but they were entirely separated and taught by two teachers.

Hittleman (1988, p. 28) identifies that thinking processes in reading and writing that create the meaning are closely connected. He further states that "the act of composing text allows students to learn how text work. They learn how to organize information purposes for communicating, and how to address their writing to a particular audience." The focus on the process of reading and writing has been identified crucial to mean connection because. Rubin and Hansen (1984) identify three areas of knowledge that help communicate meaning in both reading and writing (as cited in Savage, 1998)

1. Information knowledge, including topic knowledge and grammatical background that both readers and writers construct (Rubin and Hansen,1984)

2. Structural knowledge, including the organizational structure or patterns that writers use when writing and reader recognize when reading. Using the appropriate structures helps convey the meaning of a particular text. Similarly readers employ their knowledge of the structural organization to arrive at the intended meaning. This is important for ESL/EFL teachers and students in which they apply this concept in their writing and reading classrooms. This also effectively raises the students' awareness about this relationship. This issue is so essential to ESL students and more essentially to EFL students who really need to observe this kind of relationship in a concrete way.

3. Transactional knowledge, which implies that writing is used as a means of communication between writers and readers. This concept is indeed beneficial to writing students. If truly appreciated, students are likely to care about the meaning when writing. I believe that this is the role of the teachers who should develop this sense of relationship between reading and writing.

\section{2- Language Connection}

In addition to the meaning connection, reading and writing are connected through language understanding. Language connection here is referred to language comprehension. As students read and write, they develop competencies about reading and writing and after all their language development become obvious. Kelly (1990) argues that students who read and write about what they read understand better (as cited in Savage1998).

Writing requires students to attend to specific use of vocabulary. This is a major concern in second language writing. Specific use of vocabulary implies that students understand how to use the language items. In other words, the more students vary their use of vocabulary, the more language competent they are. Similarly, introducing students to different patterns of sentences in reading is likely to increase their level of understanding the language and eventually will influence their writing complexity. What is important here is the teachers' role in creating this relationship by drawing the students' attention to systematic continuum of reading and writing.

\section{3- Instructional Connection}

This connection serves for better implementation of the idea of bringing reading and writing together into classrooms. Savage (1998) believes that teaching one skill necessary involves teaching the other. Shanahan (1988) proposes seven instructional principles between reading and writing. Among these seven principles, five principles are related to ESL writing students:

1. Reading and writing need to be taught.

2. The relationships between reading and writing should continuously be emphasized in classrooms.

3. Reading-writing connection should be made explicit.

4. Content and process relationships should be emphasized. Students need to know that meaning is clear and how they make it so. 
5. Reading and writing should be taught in a meaningful context.

Although these principles seem to be obvious, none of them was implemented in the four-year college that I attended for my undergraduate study. The focus on reading was primarily on vocabulary building. The process of instructional reading was totally ignored. Writing was not better. I finished all of the four years without knowing anything about the "writing process." I believe that Shanahan's instructional principles should be taken as a model for language teaching, especially for designing integrated courses of reading and writing.

\section{First Language Vs Second Language Schemata in Writing}

ESL learners who come from different background may form different images for some concepts that exist in both languages. Marriage, for example, might be viewed differently by people who come from different backgrounds. Arab students might write about marriage from only one point of view, "arranged marriage." However, this concept may imply "love marriage" which does not exist in the Arab culture. This means that ESL writers should develop specific schema of any topic when they write about it in the target language.

Schema theory is defined as the previously acquired background knowledge structures. Omaggio (2001) states that schema theory basically implies that any given text does not convey any meaning by itself; rather the readers or listeners form the meaning according to how they view the text in terms of their previous background knowledge. This means that previous knowledge will likely influence readers and they process language comprehension.

Thus when ESL/EFL students write about any topic, their ideas, organizations, and structures are likely to follow their first language style. Therefore, reading in SL helps students develop better structural, or organizational schemata that conform to the target language. Reading has an effective role on forming or changing students' first schemata. McNeil states that text information can affect students to change their schemata (as cited in Noyce \& Christie, 1998). For example, if Arabic speakers of English are asked to write about a script of "eating out in American restaurants", they might not be able to accurately describe American restaurants because, for instance, most American restaurants or hotels have large lobbies which is completely not the case in Saudi Arabia where most restaurants have cozy lounge areas. Yet, having the students read about the target language scripts is predisposed to alter their images and ,hence, start to approach different schemata.

The idea of integrating reading and writing is not new. Krashen (1984) believes that sustained reading results in writing competence. In other words, he argues that reading provides input for writing. Yet, this paper tries to focus mainly on assigning different reading texts to ESL/EFL students as a preparation for writing compositions or essays. This paper comes as a reaction to my experience when I was an undergraduate student in my country where reading and writing were, and unfortunately still, taught as a two-separate field. I very well remembered that the students feel nervous when our professor assigned us to write compositions because students did not know what to write and how they should start writing. Later on, I took a private course about writing and found out different techniques that prompted my writing ability. One of these important techniques was reading for the purpose of writing compositions. This strategy empowered my writing in different ways that clearly relate to the two theories mentioned above, whole language approach and schema theory.

Reading for writing provides models for ESL/EFL students to use for writing. A model is a sample of writing that is used for pedagogical purposes. These models allow low proficient students to increase their critical thinking about the topic they are going to write about. The use of models in ESL/EFL is justified by the formal schemata of most forms of academic and technical writing in English. Formal schema, often known as textual schema, refers to the organizational forms and rhetorical structures of written texts. Reid (1989) believes that ESL students should approach the cultural constraints of the U. S. academic writing assignments.

\section{ARABIC RHETORIC VERSUS ENGLISH RHETORIC}

The structure of compositions in English differs completely form that in Arabic, for example. In English, composition style follows a consistent structure. An essay has three main parts: an introductory paragraph, a body paragraph (usually two or more paragraphs), and a conclusion. It is beyond the scope of this paper to discuss each part in details. Yet, according to Oshima and Hogue (1991), getting started or writing an introductory paragraph, for instance, is the most difficult part. They pointed out that the introductory paragraph has to have a thesis statement that controls the whole essay and which sometimes is violated by writers. They additionally state that the introduction has four functions:

- It introduces the topic of the essay.

- It gives a general background of the topic

- It often indicates the overall "plan" of the essay.

- It should arouse the reader's interest of the topic. (p. 101)

ESL students should be provided with reading texts that enable them to develop the sense of formal writing schemata because according to the contrastive rhetoric, different languages imply different rhetorical patterns and different structural organization of the text (Grabe \& Kaplan, 1989). Arabic learners of English are supposed to encounter an 
explicit difference between their language and English because the two languages indicate clear rhetorical contrasts. Reid (1989) states this rhetorical difference:

...Arabic is a traditional poetic language that the skill of writing is considered extremely difficult, a skill that only the gifted possess, and that the presentation of written material in Arabic relies on philosophical(abstract) statementsthe audience "reads between the lines," drawing conclusion and extending the information. However, U.S. academic prose requires containing a single main idea supported by facts, examples, or description. U.S. students learn to prove it or cut it!" (p.223)

Similarly, Kamel (1989) mentions that the Arabic language differs from English in that Arab writers usually start with a long introduction without stating any statement of thesis. This actually contradicts the writing convention in English which is stated above. Grabe and Kaplan (1989) show that ESL learners can simply approach these differences by reading.

Although I studied English at the college level in Saudi Arabia, my writing ability did not improve as much as it would mirror the intensive courses that I took in language skills in, general, and in writing, in particular. When I finished my undergraduate school, I applied to take the TOEFL. I got satisfactory scores in the all the test sections except in the writing section. Consequently, I took a special writing course and soon realized that I did not follow academic writing. I discovered that I violated many writing rules and organizations. Although I took several writing courses in my undergraduate study, I wouldn't succeed to present an academic piece of writing in the TOEFL Test. Later I realized that previously read text before writing would help to visualize and embody ideas and knowledge into the writing task.

\section{What DoEs READING PROVIDE FOR WRITING?}

\section{1- Organization}

Even within the language itself, writers follow different styles according to the genres of the topic. For example, writing a story differs from writing a problem-solving task. Similarly, the style of writing a comparison between two objects, or between two concepts is expected to be different from writing a technical topic. Noyce and Christie (1998) claim that reading is likely to attract learners' attention to different models of types and styles of writing. They also say that research shows that students' writing competence relate to the types of texts they read.

However, there is an important issue that should be taken into account when using models of writing. Watson (1982) believes that models are useful, yet misleading. He suggests that students are encouraged to treat a model as resource of information and organization, not as an ideal one. This is very important because a writing model is used to facilitate writing as the students explore some models of reading. However, Raimes (1983) provides a good solution to this problem. She states that the problems associated with the use of models may be avoided if the model is viewed not so much as a straitjacket but as a resource for possible ways of organizing information. She further says that "the model becomes not what he should do but only an example of what he could do" (P.127).

Also, reading specifically for writing a composition provides learners with content schema (background knowledge) about the topic they write about. This knowledge is essential for writers because according to Noyce and Christie (1998), "without schema, writers would have nothing to write about" (p.8). It is assumed that good writers follow some writing techniques, or processes that help them activate their prior schemata about the topic of their writing. Yet, ESL/EFL writers are completely different because their prior knowledge most probably relates to their first culture which may contradict with the target culture. Thus reading for writing may enable ESL/EFL writers to compose in terms of the target language point of view. If the reading correlates with their prior schema, it will confirm their prior schema and thus leads to a well-communicative topic. On the other hand, if the reading selection does not conform to the prior knowledge of the writers, this would probably lead the writer to reconsider his/her content and eventually result in building an appropriate schema that correlates with the language used.

\section{2- Content}

ESL/EFL learners of writing are recommended to read as much as it may provide them with the necessary information needed to write their essays. Reading in this stage functions as a stimulus for writing. It is crucially important for ESL/EFL writers to enrich their knowledge through reading about their assigned topic. This knowledge is likely to promote the growth of writing. Shih (1986) discusses five approaches of instructing students in content-based writing. One of which, as he called, is "content-based academic writing courses", in which students would read some passages that relate to the topics of their writing assignments. The role of the readings aims to build appropriate schemata and provide students with new information for their writings.

ESL/EFL students come to the classroom with different backgrounds. Students have their own perspectives about the world. Indeed, even students coming from a particular ethnic group might have different perspectives about different values. This cultural variation insists on having students refer to text before they just start writing. Reading in this context helps the students reform their perspective toward the target language. Reading can do this. Reid (1990) believes that good readers are those who selects, read, and respond to texts. Nystrand (1990) argues more that writer's perspectives of the issue might change as they read and search for more information.

Like brainstorming, recollecting, planning, which are some techniques of writing process, reading also can be used as a prewriting process to generate ideas for writing (Noyce and Christie,1998). Similarly, Zamel (1987) emphasizes that 
reading represents one strategy of generating ideas in a process approach to writing. Thus, reading in this stage functions as source of information that helps the writers to composes well-contended composition. Moreover, reading about the topic may enrich the writers with some more updated information that they may not have it in their prior knowledge. This is why reading is such a powerful prewriting strategy" (Elder, 1990). Furthermore, this process is predisposed to help the writers understand their topic more and thus help them critically process their writing because reading in this stage will trigger learners' attention to more valuable and recent issues.

\section{3- Vocabulary}

Another aspect about reading for writing relates to the vocabulary use that reading provides for ESL/EFL writers. Reading is one of the best strategies for learning vocabulary simply because words are presented in context. This strategy represents a major element for ESL/EFL students who mostly learn vocabulary in isolation. Al-Hazmi (2000) made a research study on Saudi learners and found out that most of the participants suffer a great loss of vocabulary due to learning vocabulary in meaningless situations. Many research studies show that absolute memorization of vocabulary is not always an effective strategy particularly in isolation. According to Robins (1993) words never exist by themselves. Rivers (1968) demonstrated the ineffectiveness of learning vocabulary in isolation. Similarly, Nation (1990) tells us that repetition of words is not helpful for retrieval of these words. O'Malley and Chamot (1990) emphasize that one can memorize vocabulary, but this knowledge cannot be brought into play in real situations or writing.

Having stated the ineffective role of learning vocabulary in isolation, it is now so evident that reading supplies learners with contextualized words which helps them use these words appropriately in writing. This is crucially important for ESL/EFL learners. From my experience as a student and a writing teacher for EFL students, I notice that most of my students do not use specific words in their writings. They just use some general words, which in most cases do not convey the exact meaning. Also, due to the lack of vocabulary bank, they always repeat themselves when they write compositions even if they write different topics. Finally, they most often talk around their ideas and try to explain it because they do not have the precise words that help them express their thoughts directly.

Comparably, when vocabulary items are used as a reaction for writing, it is more likely that they will stay longer than when they are just orally practiced. I once was given an assignment to write about Lipton. Since I did not have enough background about this topic, I looked for some articles that may expand my knowledge about it. I came a cross the word brew. I found it interesting and meaningful to use it in my composition. Although, I did not experience this word before and have not used after, I still remember this word in terms of spelling, meaning, and use simply because I processed this words and eventually decoded it into my long-term memory.

Thus, according to cognitive approach, when learners prepare themselves to write through reading, they will be able to turn vocabulary from short-term memory to long-term memory. This happens because they read, encounter words in context, examine these words they want to use, and use them in their writing. Thus they continuously process these words and turn them from declarative knowledge into procedularized one, which is an essential elements for words to be fully understood. If vocabulary items are not appropriately perceived, they may not be appropriately used. employ his or her declarative knowledge of vocabulary appropriately in real situations. Robinson (1993) states that in declarative knowledge, words have particular meanings, and the procedures that learners use decide this declarative knowledge.

\section{4- Motivation}

One more point that reading adds to ESL/EFL writers relates to motivation. Noyce and Christie (1998) point out that reading of literature can function as a source of motivation for writing. They also state that reading encourages students to write in several ways. When writers become aware of the topic and expand their schema about it, they are likely to be interested and thus will devote much time for writing. This is very important for ESL/EFL students because writing represents one of the major problems that needs special attention so that learners can get motivated. Zamel (1992) argues that reading should precede writing in a way that provides a system to internalize and act as a stimulus for writing because it provides a subject matter to write about. This is significant change to ESL/EFL students who might find it so hard to choose their area of focus for their compositions.

Staley (1997) strongly argues that reading motivate ESL learners of writing to have passion when engage in writing. He reiterates that although ESL students present fairly enough quantity of writing and grammatically correct pieces of writing, they seem to be missing the important connection between their reading and their role in the world around them. He incorporates "read aloud" strategy where students would listen to the teacher reading a short passage about a particular topic. The writing topic that Staley asked his students to write about was a letter to the president of France regarding their feeling about nuclear testing. Staley posits that the some students were not motivated to write about this letter because it did not seem important to them. However, he brought of a children's book and read aloud a story about Hiroshima bombing in 1945. After attentive listening to the story, the teacher gave them a work sheet where they answered some question related about the topic. Later, he asked them to write the letter to the president about the misfortunes of atomic bombs. Staley pointed out that all the students got motivated to write the letters because according to Staley the students could make a connection between nuclear testing and their own lives. He also suggested that they could form their own opinions about the topic. Therefore, they can easily transfer these feelings into thoughts on papers. 
Furthermore, students may develop their independence toward writing after they are exposed to different styles through reading. In other words, within time, as learners read for different organization, sentence types, and stylistic patterns, they are likely to transfer these features to their writing unconsciously. In fact, Johnson (1991) found that while writing, the students make use of the reading passages by extracting the concepts presented, following similar patterns of organization, and developing awareness of writer/reader relationship." This is true because learners follow the same way language is presented to them.

\section{ESL/EFL READING-WRITING TEACHERS}

The scope of this paper is limited but its nature and purpose extends out to teachers of ESL/EFL writing. Throughout the whole paper, I was trying to approach the effective side of integrating reading into writing in classrooms. Although the connection between the two skills is not new, especially to L1 students, the case is completely different with L2 students. L2 students' exposure to language, particularly to reading, is not the same as L1 students. Therefore, the reading-writing connection with L1 is hard to be exactly applicable to L2 without specific modifications that meet ESL/EFL natural settings. Students need continuous and intensive reading so that they can bring the reading styles into their writings. However, ESL/EFL student's readings are limited to the least minimum time and chances that enables them practice reading. This inadequate chance doesn't allow them to realizes and acquire different stylistic patterns. EFL college students in Saudi Arabia, for instance, beside their English courses, systemically study different courses introduced to them in a totally different language, e.g., Arabic. This, consequently minimizes their exposure to reading English texts. Therefore, the emphasis on explicit reading for writing, or the direct connection between the two skills should be given more attention. What has been mentioned so far in the previous sections relates closely to the importance and merits of this connection based on it's advantages and the nature of English rhetoric versus Arabic rhetoric. Additionally, the nature of EFL students interplays in this context. The question, then, becomes how this explicit connection can be presented in composition or writing classrooms. In other words, what do ESL/EFL teachers of writing need in order to bring reading and writing together in classrooms.

Teachers' knowledge of classroom composition:

This section will explore ESL composition knowledge and experience in teaching second language composition with connection to reading and how they can bring together reading and writing to the classrooms. Freeman (1990) believes that the classroom constructions that teachers choose evolve from their individual teaching experiences and beliefs. Freeman (1990), furthermore, argues that teachers structure their classrooms the same way they were taught. More specifically, According to Corbett (1990), a number of college composition teachers who lack professional graduate training are likely to recreate the same models of some teachers who taught them. Therefore, Robinson (1991) blames a group of recently hired teachers staffing composition classroom for not only being untrained in composition but who " never exhibit the slightest knowledge of the books or articles that are shaping our field nor the slightest embarrassment about their ignorance." (as cited in Kroll, 11993)

Kroll (1993) gave an example of a teacher construction of reading-writing classroom. In that context, the teacher gave the students a text of 1,000 words and asked them to read it for the next class. When they met for next class, he asked the students several questions regarding text comprehension. Then, he selected some apparently new vocabulary items and asked the students to guess meaning from context. If the text is full of transitions, citations from sources, or any other features such as exemplary topic sentence, he will call their attention to these basic rhetorical properties of the assigned text. Having discussed the reading tasks, he asks the student to write a first draft in which they give their own opinion about the subject matter or compare the ideas presented in the text with other ideas presented in previous texts.

According to Kroll, this class includes three main instantiations: reading and writing as springboard of a topic to write about; (2) reading to provide background information; and (3) reading to serve as a model for particular stylistic patterns. To my surprise, although these three ways are included in this class, Kroll criticize that none of these ways sufficiently deal with the rhetorical activities. My surprise premises from the fact that none of these three instantiations are used in my college where I took several composition courses and never been exposed to these instantiations. Needles to say that rhetorical activities were never illustrated or highlighted at my undergraduate classes. This situation dictates a necessity that ESL/EFL composition teachers should receive structural composition classroom training. I believe that EFL composition teachers and students, at least to my experience, did not consider rhetorical aspects in their writing classrooms.

Actually, teaching students to write better with the use of reading requires that teacher improve their knowledge of writing and writing teachings. One important aspect that writing teachers should do in order to develop their student's writing is to teach them how to view their own writing as external readers. This issue is so essential to writers and needs special attention and teachers' training. This is very important for three reasons:

- How do students distance themselves from their own writing?

- How do students bring their knowledge to their texts and improve them for subsequent drafts (Kroll, 1993)?

- How do teachers help students treat their own writings as audience?

ESL composition teachers can not provide theoretical and practical answers to these questions unless they receive professional training on writing classroom constructions because according to Raimes (1985), less proficient writers in L1 and L2 experience difficult in imagining themselves as public readers. Skilled writers, on the other hand, 
consciously involve themselves in the audience position. To help students understand this issue, writing teachers need to understand what readers need as they read which requires that teachers incorporate the audience's needs into the students' writing for effective connection of reading and writing. The questions remain what types of strategies that writing teachers should employ to bring reading and writing in better relationships. This question needs more research and examination.

\section{CONCLUSION}

This paper serves as a foundation for more studies and empirical research on reading for writing compositions for ESL/EFL students. It is evident that this paper is mainly theoretical because using explicit ESL reading as a part of writing process is still in its infancy. Yet, it calls teachers and students to apply this concept in ESL/EFL writing activities. The main point of this research is to call the attention of L2 students and teachers to the explicit reading and writing relationship and how this relationship may develop ESL writing competence.

While doing this paper, different considerable issues emerged that need further research so that explicit ESL/EFL reading for writing can be more explored. Some of these issues include the role of teachers and students in the classrooms, the amount of reading, the level of reading, the types of reading texts: authentic or pedagogical, and the types of activities of reading for writing. These issues and others must not be overestimated because they represent the practical aspects of this paper which are crucially important for successful implementation of ESL explicit reading to writing connection.

\section{REFERENCES}

[1] Al-Hazmi, H. (2000). Lexical attrition of some Arabic speakers of English as a foreign language: A study of word. http://iteslj.org/Articles/Al-Hazemi-Attrition/ Loss (accessed 24/2/2010).

[2] Archibald (Eds.). Contemporary linguistics: An introduction (4 ${ }^{\text {th }}$ ed., pp. 591-623). Bedford/St. Martin's, Boston

[3] Coady, J. (1993). Research on ESL/EFL vocabulary acquisition: Putting it in context. In T. Huckin, M., Haynes, \& J. Coady (Eds.), Second language reading and vocabulary learning (pp. 3-23). Norwood, NJ: Ablex Publishing Corporation.

[4] Edelsky, C. (1986). Writing in a bilingual program. Norwood, N.J: Ablex Publishing Corporation.

[5] Elder, D. (1990). Writing to write: Process, collaboration, communication. NY: Macmillan Publishing Company.

[6] Flihive, D. E. \& Bailey, N. H. (1993). Exploring reading and writing relationships in adult second language learners. In J.G. Carson \& I. Leki (Eds.), Reading in the composition classroom: Second language perspectives (pp.85-104). Heinle and Heinle Publishers.

[7] Freeman, D. (1990). Learning to teach: Intertteaching" as evolution of pedagogical expertise. Paper presented at the $24^{\text {th }}$ Annual TESOL Convention, San Francisco, CA.

[8] Freeman, Y. S., \& Freeman, D. E. (1989). Whole language approaches to writing with secondary students of English as a second language. In D. M. Johnson, \& D. H. Roen (Eds.), Richness in writing: Empowering ESL students (pp. 177-192). NY: Longman.

[9] Grabe, W., \& Kaplan, R. B. (1989). Writing in a second language: Contrastive rhetoric. In D. M. Johnson, \& D. H. Roen (Eds.), Richness in writing: Empowering ESL Students (pp. 263-283). NY: Longman.

[10] Hittleman, D. R. (1988). Developmental Reading, K-8: Teaching from a Whole Language Perspective. Columbus, Ohio: Merrill.

[11] Kamel, G. W. (1989). Argumentative writing by Arab learners of English as a foreign and second language: An empirical investigation of contrastive rhetoric. Unpublished doctoral dissertation, Indiana University of Pennsylvania, Indiana, PA.

[12] Krashen, S. D. (1984). Writing: Research, theory and application. New York: Pergamon.

[13] Kroll, B. (2001). Consideration for teaching an ESL/EFL writing course. In M. Celce-Murcia (Ed.), Teaching English as a second or foreign language ( $3^{\text {rd }}$ ed., pp. 219- 232). Heinle \& Heinle.

[14] Kroll, B. (1993). Teaching writing is teaching reading: Training the new teacher of ESL composition. In J.G. Carson \& I. Leki (Eds.), Reading in the Composition Classroom: Second Language Perspectives (pp.61-81). Heinle and Heinle Publishers.

[15] Natio, I. S. P. (1990). Teaching and learning vocabulary. Rowley, MA: Newbury house.

[16] Noyce, R. M., \& Christie, J. F. (1989). Integrating reading and writing instruction in grades K-8. Boston: Allyn and Bacon.

[17] Nystrand, M. (1990). Sharing words: The effects of readers on developing writers. Written communication, 7 (1), 3-24.

[18] Omaggio, A. C. (2001). Teaching language in context. Boston: Heinle\& Heinle.

[19] O’Malley, J. M., \& Chamot. A. U. (1990). Learning strategies in second language acquisition. Cambridge: Cambridge University Press.

[20] Oshima, A., \& Hogue, A. (1991). Writing academic English. NY: Longman.

[21] Raimes, A. (1983). Techniques in teaching writing. NY: Oxford University Press.

[22] Raimes, A. (1985). What Unskilled ESL Students Do as They Write: A Classroom Study of Composing. TESOL Quarterly, 19, 30-59.

[23] Ramirez, A. G. (1995). Creating context for second language acquisition. NY: Longman.

[24] Reid, J. (1990). Historical Perspectives on writing and reading in the ESL Classroom. In [25] J.G. Carson \& I. Leki (Eds.), Reading in the Composition Classroom: Second Language Perspectives (pp.33-60). Heinle and Heinle Publishers.

[25] Reid, J. M. (1989). English as second language composition in higher education: The expectations of the academic audience. In D. M. Johnson, \& D. H. Roen (Eds.), Richness in Writing: Empowering ESL Students (pp. 220-234). NY: Longman.

[26] Richards, J. C., \& Rodgers, T. S. (2001). Approaches and methods in language teaching. Cambridge: Cambridge University Press.

[27] Rivers, W. M. (1968). Teaching foreign-language skills. Chicago: The University Press. 
[28] Robinson, P. J. (1993). Procedural and declarative knowledge in vocabulary learning" Communication and the language learners' lexicon. In T. Huckin, M. Haynes, \& J. Coady (Eds.), Second language reading and vocabulary Learning (pp. 3-23). Norwood, NJ: Ablex Publishing Corporation.

[29] Savage, J. F. (1998). Teaching reading and writing: Combining skills, strategies, \& literature. Boston, MA: Mc Graw Hill.

[30] Shanahan, T (1988). The reading-writing relationships: Seven instructional principles. The Reading Teacher, 41, 636-647.

[31] Shih, M. (1986). Content-based approaches to teaching academic writing. TESOL Quarterly, 20, 617-648.

[32] Staley, A. (1997) Reading aloud: Bringing whole language into the ESL writing classroom. http://langue.hyper.chubu.ac.jp/jalt/pub/tlt//mar/aloud.html (accessed 24/2/2015).

[33] Watson, C. (1982). The use and abuse of models in the ESL writing class. TESOL Quarterly 16, 5-14.

[34] Zamel, V. (1988). Recent research on writing pedagogy. TESOL Quarterly, 21, 697-715.

[35] Zamel, V. (1992). Writing one's way into reading. TESOL Quarterly, 26, 40-62.

Ali Saleh Alghonaim was born in Buraidah, Saudi Arabia, 1973. Right now he is a faculty member at Qassim University, English Language and Translation Department. He runs some administration positions, such as chairmen of the English language and translation, Supervisor of Graduate studies, and dean of College of Arts and Humanities at Qassim Private colleges.

He earned his Ph.D degree in Applied Linguistics from Indianan University of Pennsylvania in USA in 2006. He also received his MA degree in Applied Linguistics from Indianan University of Pennsylvania. His Bachelor degree was from Immam University in Riyadh, English Department. 